\title{
INNOVATIVE TECHNOLOGY OF HORIZONTAL PROTECTIVE SHIELD ARRANGEMENT USING INJECTION
}

\author{
Scientiffic paper/ Znanstveni rad \\ Aleksandr Meneylyuk \\ (Received: 16 August 2017; accepted: 20 December 2017) \\ Odessa State Academy of Civil Engineering and Architecture, Department of Technology of Building Industry, Full \\ Professor \\ Anatoliy Petrovskiy \\ Odessa State Academy of Civil Engineering and Architecture, Department of Technology of Building Industry, Full \\ Professor \\ Aleksandr Borisov \\ Odessa State Academy of Civil Engineering and Architecture, Department of Technology of Building Industry, \\ Associate Professor \\ Aleksey Nikiforov \\ Odessa State Academy of Civil Engineering and Architecture, Department of Technology of Building Industry, \\ Postgraduate Student \\ Corresponding author: aleksey-nikiforov@mail.ua

\begin{abstract}
This study focuses on developing methods of anti-contagious underground shield arrangement. The results of experimental laboratory and full-scale in situ studies of the horizontal protective shield arrangement are discussed, and the method and laboratory equipment to conduct such research are developed. Moreover, the different embodiments of the shielding apparatus are studied using bentonite, sodium hydrosilicate in combination with calcium chloride, and a waterproofing soft-elastic injection resin. The analytical and graphic dependencies of the changes of the shield filtration coefficient from different injectable formulations are presented. In conclusion, the most economically efficient technological modes of horizontal shield arrangement are the usage of soft-elastic waterproofing injection resin with drilling the wells at a $0.3 \mathrm{~m}$ distance from each other.
\end{abstract}

Keywords: anti-filtration protective shields; horizontal directional drilling; bentonite; soil filtration coefficient; sodium hydrosilicate; injection resin

\section{INOVATIVNA TEHNOLOGIJA UGRADNJE HORIZONTALNOG ZAŠTITNOG SLOJA POMOĆU INJEKTIRANJA}

Sažetak: Rad je posvećen razvoju metoda ugradnje podzemnih zaštitnih slojeva za zaštitu od onečišćenja. Razmatrani su rezultati eksperimentalnog laboratorijskog i terenskog ispitivanja ugradnje u stvarnom mjerilu. Razvijena je metoda i laboratorijska oprema za provedbu ovakvih ispitivanja. Proučavane su različite izvedbe zaštitnog sklopa koristeći bentonit, natrijev hidrosilikat u kombinaciji s kalcijevim kloridom i hidroizolacijskim mekoelastičnim injekcijskim smolama. Prikazane su analitičke i grafičke zavisnosti filtracijskog koeficijenta zaštitnog sloja izvedenog od različitih injekcijskih formulacija. Zaključeno je da je ekonomski najisplativiji način izvedbe horizontalnog zaštitnog sloja pomoću mekoelastičnih hidroizolacijskih smola s međusobnim razmakom bušotina od $0.3 \mathrm{~m}$.

Ključne riječi: antifiltracijski zaštitni slojevi; horizontalno bušenje; bentonit; koeficijent filtracije tla; natrijev hidrosilikat; injekcijska smola 


\section{INTRODUCTION}

The analysis of the problems arising from the disposal of the consequences of the Chernobyl accident showed that the scale of the impact and the necessary financial and technical resources play a dominant role in the localization of pollution and reduction of radioactive substance emissions into the environment. The protective shield arrangement by horizontal directional drilling can be used to protect groundwater from pollutant migration. Numerous methods for impervious shield creation exist (e.g., "sheeting wall," shield arrangement or injection in open pit, and hydraulic fracturing), but their analysis showed low economic and environmental performance. According to these criteria, the use of horizontal directional drilling is preferred. The present study can have a social significance because it is supposed to protect the population from the consequences of contamination with radionuclide polluted water.

\section{AIM AND TASKS OF THE STUDY}

This study aims to determine the optimum operating modes of the horizontal protective shield arrangement by horizontal directional drilling and injecting the soil with different compositions. The following tasks are stated in keeping with this purpose:

1. analysis of information sources on the study subject;

2. development of the technology concept;

3. development of research methods and creation of the laboratory bench;

4. experimental studies using various injections;

5. analysis of the experimental results; and

6. economic analysis of the most effective technological modes of underground shield arrangement.

\section{ANALYSIS OF INFORMATION SOURCES}

Many studies confirmed that the soil and groundwater in the $30 \mathrm{~km}$ exclusion zone around the Chernobyl nuclear power plant are contaminated with a large number of radioactive and chemically active substances. Almost all radioactive materials (e.g., cesium (Cs), strontium (Sr), and transuranic isotopes plutonium (Pu) and americium (Am)) exist in the top surface of the undisturbed soil layer [1]. The activity ratios of the 99Tc/137Cs ratios in the soils were calculated as approximately $3.7 \times 10^{-5}$ to $1.3 \times 10^{-4}[2,3]$. Along with a high content of $90 \mathrm{Sr}$ (of an order of $n \times 1000^{-n} \times 10,000 \mathrm{~Bq} / \mathrm{L}$ ), the groundwater in the Red Forest radioactive waste dump site in the Chernobyl exclusion zone showed elevated concentrations of calcium $(\mathrm{Ca})$ and kalium $(\mathrm{K})$, and had more acidic $\mathrm{pH}$ values compared to the "background" aquifer conditions $[4,5]$. The radiocarbon (14C) values of humic and fulvic acids ranged from $-68 \%$ to $+75 \%$, and were $\sim 400 \%$ o lower than those of non-contaminated environments [6]. Microscopic analyses of waste materials and leaching experiments showed that $10-30 \%$ of the radioactive inventory is associated with chemically extra-stable $\mathrm{Zr}-\mathrm{U}-\mathrm{O}$ particles [7]. The $36 \mathrm{Cl} / \mathrm{Cl}$ ratios measured in groundwater, trench soil water, and leaf leachates are $1-5$ orders of magnitude higher than the theoretical natural $36 \mathrm{Cl} / \mathrm{Cl}$ ratio [8]. Studies showed that all these pollutants can get through soil and contaminate the groundwater [9].

As a rule, the main sources of pollution are concentrated in the so-called bury repositories, which contain radioactive waste buried in the ground. When water passes through these structures, pollutants enter the groundwater [10-12]. The study of information sources confirmed that digging up and transporting this waste can be dangerous [13]. Several sources stated that the pollution by radionuclides does not end in time, can contaminate the ground, and can be transported by environing, water, plants, and living creatures long after the disaster [14, 15]. Moreover, studies confirmed that protecting the groundwater from secondary contamination by underground impervious shield arrangement is effective [16].

As a result of the analysis of known sources on the subject, the existing methods of the anti-contagious shield arrangement are concluded to be ineffective for radioactive waste localization. Some of these methods are described as follows:

Meneylyuk, A, Petrovskiy, A, Borisov, A, Nikiforov, A 
- Jet grouting technology - Creating solid arrays consisting of cross-sectioned soil-cement columns is possible, but has the disadvantage of needing to drill wells through the structure itself to create a screen under an existing structure [17-19].

- Drilling-mixing technology - The use of a drilling tool allows to enter the binder in a dry and water-cured state. The blades located on the drilling tool-mixer rigidly determine the column diameter and serve for grinding and mixing of the initial soil with the binder being fed into the borehole. The application of the drillingmixing technology to create artificial horizontal anti-filtration screens is possible before the construction of various types of buried structures, but what is much more problematic is its use under existing structures [19, 20].

- Hydraulic fracturing of soil - A series of wells of a given depth are drilled at a certain distance from each other. The mouth of one of the wells is sealed and fed with a hardening solution under pressure. A hydraulic rupture of the soil occurs if the soils are impermeable, with the output of the solution in the next wells. The use of the hydraulic fracturing method has many disadvantages: the cracking process is practically uncontrollable; the closing of different parts of the screen is extremely difficult, such that the solidity of the screen is not guaranteed; and large losses of the solution are possible [19-21].

In recent years, several attempts were made to develop an efficient technology for such works [22], but the use of the horizontal directional drilling (HDD) technology for groundwater protection shields can be more promising from an economic or technological perspective.

One of the main sources describing the horizontal directional drilling technology is presented in [23]. This technology can be used for laying and rehabilitating underground communications and well setting with different configurations in the soil column. The arrangement of such wells will allow their usage to supply an injectable solution into the desired region of the underground space. Such an injection at the appropriate technological modes will make it possible to form an impervious shield at the source of the radiation contamination.

The operation, which increases the complexity of work on the HDD, is the installation of equipment in a specially constructed pit [24]. The drilling rig placement on the earth surface can reduce the labor costs and cash cost per arrangement of the horizontal directional wells.

During the arrangement of the curved shape wells, ensuring the stability and accuracy of the drilling head move in the soil column is important. To that end, special nozzles and technological modes of drilling can be used [25].

All previously mentioned discussions confirm the possibility of the protective shield arrangement under burial repositories by drilling directional wells and pulling the injector into them, followed by injecting a hardening solution.

As for the effective shielding device, a binder with hydrophobic properties must be chosen. Bentonite can be considered as an effective tool for the impervious shield arrangement [26]. Its use is possible when mixed with a larger fraction material $[27,28]$. The glue properties of bentonite can be used for shield arrangement because they can prevent the spread of radioactive substances [29]. Moreover, bentonite may be used as a binder in injectable solutions because of its low dispersion [30, 31].

In addition, a combination of sodium silicate and calcium chloride can be regarded as one of the effective injectable hydrophobic substances [19].

Different polymer resins [32] can also be used as effective waterproofing materials. Studies confirmed that such resins may also be injected into the soil column, followed by solidification and the impervious shield formation [33, 34].

\section{CONCEPT OF THE PROPOSED TECHNOLOGY}

The proposed technology can provide a method for underground shield arrangements under structures. Using this method cannot only reduce the complexity and cost of projects, but can also shorten the production time.

We propose herein that the problem can be solved by the following method of impermeable shield construction. Horizontal, sloping, or curved injection wells are created starting from the surface of the Earth. The wells are pumped by an injected mortar. After setting, this mortar forms a shield.

The figures herein illustrate the proposed scheme of works on the underground shield arrangement. Figure 1 shows a vertical section through the axis of the pilot well when it is created. Figure 2 denotes the same when the injector is drawn. Figure 3 illustrates the same when the mortar is injected. Figure 4 depicts the cross-section of shield A-A.

Meneylyuk, A, Petrovskiy, A, Borisov, A, Nikiforov, A 
The multi-step drilling process is outlined in Figure 1 as follows: a number of parallel wells (6) are drilled in the ground (5) under the structure (1) from the ground surface (2) curvilinear to the structure base (4). The injector (7) is pulled after completion of well drilling (6) (Figure 2). The dilator (10) and the head with a hinge driving force (swivel) (11) are then attached to the drill rod (9) instead of the drill bit (8), and the swivel (11) is attached to the injector (7). The drilling rig (3) draws the injector (7) in the well (6) according to the project trajectory, wherein the swivel (11) rotates with the drill rod (9) not transmitting rotational movement to the injector (7). The injection mortar is fed from the supply line (12) to the injector (7), which is drawn in by the traction device (13) (Figure 3).

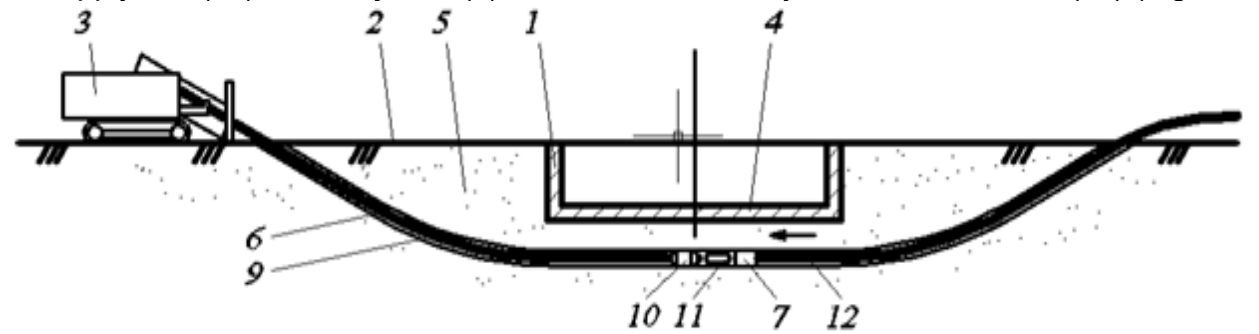

Figure 1 Pilot well drilling

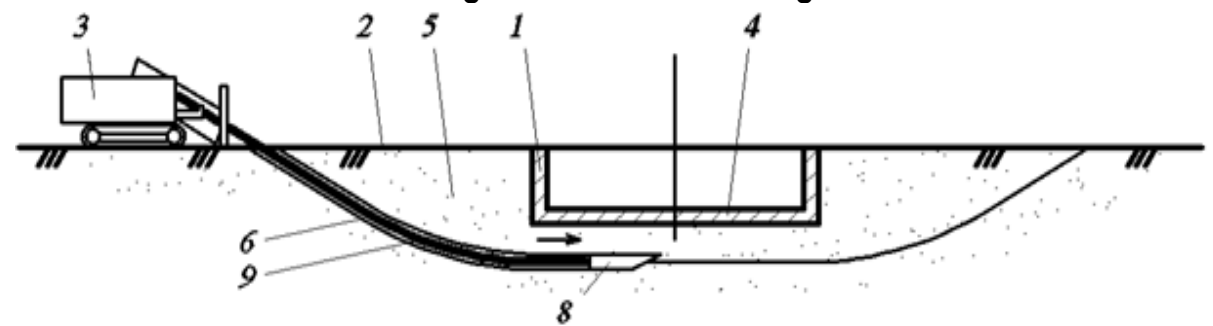

Figure 2 Drawing the injector in the well

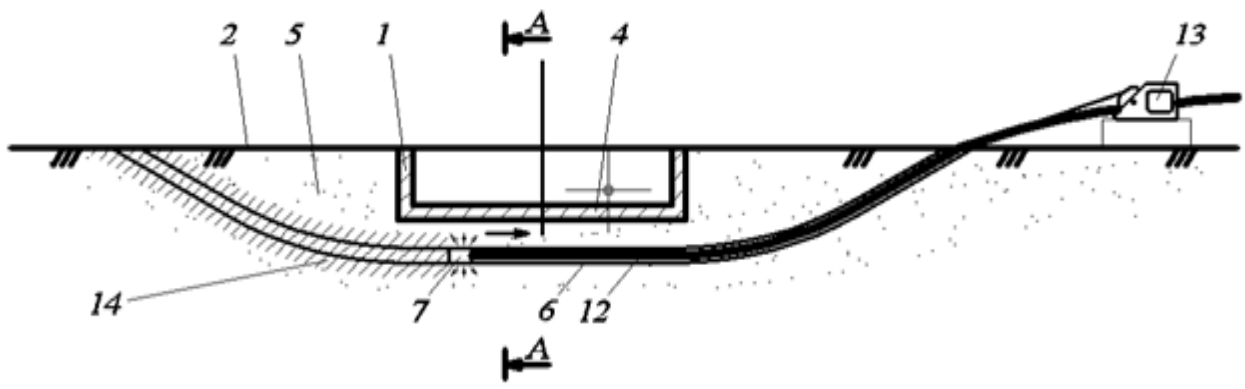

Figure 3 Injection of the hardening mortar into the well

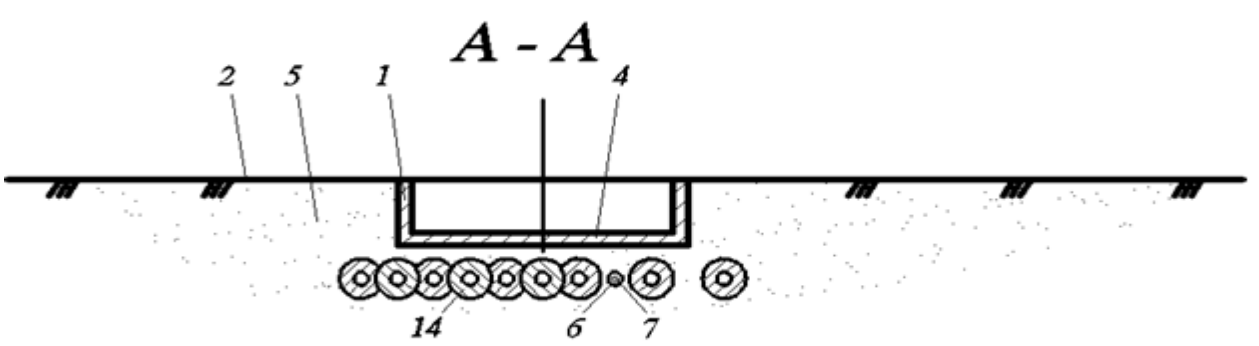

Figure 4 Cross-section A-A of the underground shield

The distance between the wells is assigned depending on the mortar distribution radius, and should not exceed two radii of the distribution zone (Figure 4).

Soil injection is produced by hardening compounds, which are selected according to the permeability of the grounds based on viscosity and time of mortar setting. The protective shield (14) is formed in the ground after mortar hardening. The shield is bent over the underground part of the building.

The proposed technology proved to be innovative as three utility model patents were acquired from the Ukrainian Intellectual Property Institute [35-37]. 


\section{METHODOLOGY OF THE STUDY. LABORATORY TEST EQUIPMENT}

The laboratory bench (Figures 5-6) was created to simulate the injection process described earlier. The bench simulated the section perpendicular to the axis of the well, wherein the injectable solution was distributed at various places away from the injection source.

The main feature of the impervious screen was its impermeability to water; hence, a soil filtration coefficient was selected as a key indicator. The filtration coefficient was determined on the test bench and calculated to the normative document method through the transition ratio $[38,39]$.

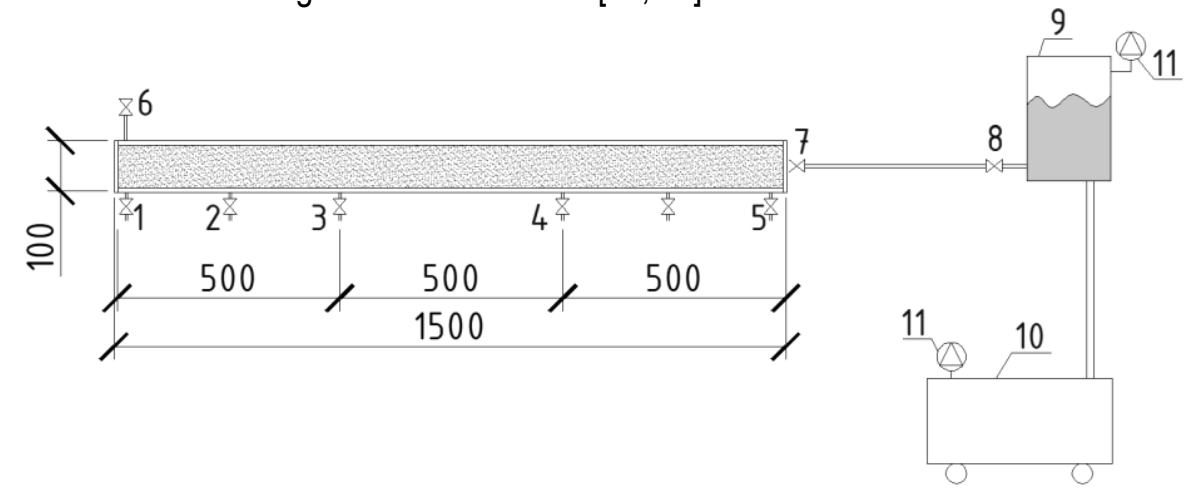

Figure 5 Scheme of the laboratory test bench for injections $1-8-\operatorname{taps} ; 9-$ mortar tank; $10-$ compressor; and 11 - gauge (dimensions are in millimeters)
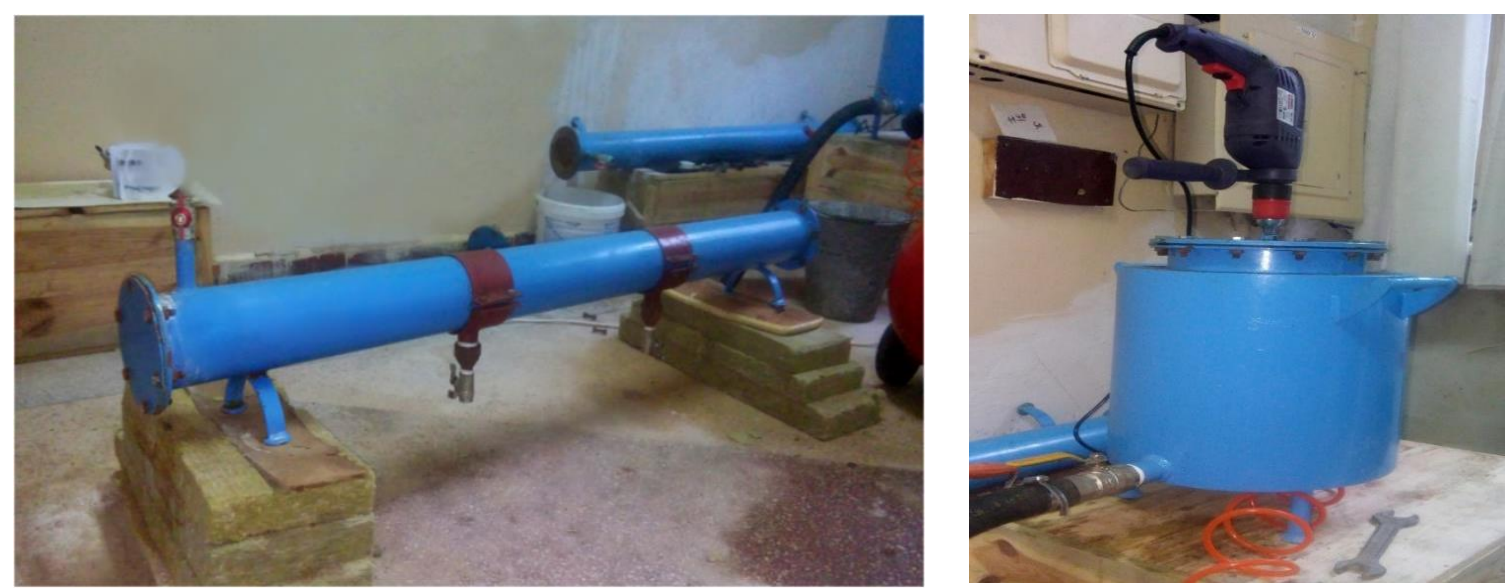

Figure 6 Laboratory test bench and mortar pumping machine

The minimum allowances of the filtration coefficient values were established according to the normative documents [40,41], in which the reliability of the impervious properties can be considered sufficient. The shield was assumed to have reliable impervious properties when the filtration coefficient value was less or equal to 0.005 $\mathrm{m} /$ day.

\section{METHODOLOGY OF THE LABORATORY BENCH INJECTION}

The test process included the following steps:

1. preparing the lab bench for the tests;

2. filling a cylindrical tank of the test bench by sand and preparing for the injection;

3. injection process with the specified parameters;

4. technological break; and

5. determination of the filtration coefficient according to the developed technique on a laboratory bench and fixing the results. 
The laboratory bench preparation for testing included threaded joint lubrication; tank installation in a vertical position to be filled with sand; and preparation of materials, tools, and instruments. Table 1 shows the characteristics of the sand used to fill the bench. Table 2 lists the characteristics of the mortars prepared using bentonite, calcium chloride and sodium hydrosilicate, and soft-elastic waterproofing injection resin.

Table 1 Physical properties of the sand to be injected during the laboratory experiments

\begin{tabular}{lc}
\multicolumn{1}{c}{ Property } & Value \\
\hline Gradation factor & 2.25 \\
Porosity, $\%$ & 40.5 \\
Bulk density, ton $/ \mathrm{m}^{3}$ & 1.6 \\
Specific surface, $\mathrm{m}^{2} / \mathrm{kg}$ & 5.4 \\
Soil filtration coefficient, $\mathrm{m} /$ day & 14.78
\end{tabular}

Table 2 Comparison of the physical properties of mortars, including bentonite, calcium chloride, sodium silicate, and soft-elastic waterproofing injection resin

\begin{tabular}{lccc}
$\quad$ Injection mortar & Density, $\mathrm{g} / \mathrm{cm}^{3}$ & Setting time, $\mathrm{h}$ & Viscosity, $\mathrm{s}$ \\
\hline Bentonite & 1.55 & - & 41 \\
Calcium chloride & 1.35 & 240 & 28 \\
Sodium silicate & 1.26 & 0.15 & 14 \\
Soft-elastic waterproofing resin & 1.15 & &
\end{tabular}

The cylindrical tank of the laboratory bench was filled in an upright position with layerwise sand compaction. Compaction was performed by ramming. Thus, the achieved compaction degree was equal to the compaction degree of sandy soil under natural conditions and checked by comparing the volume of the filled sand to the volume of the same sand in a natural bulk state. The pipe tank was brought to the horizontal position after filling.

The mortar was immediately prepared in a separate container prior to injection. The measured amounts of the components were poured into the tank and stirred by a mixer into a homogeneous mortar.

The mortar was periodically stirred during injection to maintain the solution concentration.

The mortar injection happened with the defined technological parameters: a certain pressure and a predetermined time. The crane located opposite the point of the mortar injection remained open throughout the experiment until the mortar passed through the laboratory bench, and did not start to flow through it.

Materials, such as bentonite powder, calcium chloride and sodium hydrosilicate, and soft-elastic waterproofing resin were used to prepare the mortar injection. These materials were chosen based on their pronounced hydrophobic properties.

The amount of mortar for injection was obtained by a sand porosity calculation. The ratio of the components in the mortar was chosen based on the viscosity value. The viscosity was determined using a Marsh funnel viscometer. The components were infused into the tank and thoroughly mixed with a mixer.

The injection by sodium hydrosilicate was made by the basis silicification two-compound method. In this method, the filling of pores and hardening of sand occurred as follows: sodium silicate pumped through the well filled the pores of the soil, thereby forcing the water out of them. Sodium hydrosilicate was diluted with water, and its concentration decreased. Calcium chloride injected into the well then displaced the sodium hydrosilicate solution in the pores, except for its thin film around the mineral particles. The reaction between sodium hydrosilicate and calcium chloride formed the film of the silicic acid gel. Through this film, an alkali diffused out of sodium hydrosilicate, which reacted with calcium chloride to form calcium oxide hydrate and sodium chloride. Sodium silicate, lean by alkali, gradually became a hydrogel of the silicic acid with calcium oxide hydrate adsorbed thereon. The process ended in a film thickness of up to $1 \mathrm{~mm}$ only 10 days after.

During the reaction, the initial solutions precipitated into silicic acid gel and calcium oxide, which filled the pores of the soil. The adsorption compound of silicic acid and calcium hydroxide formed the cementitious film on the surface of the sand particles. Sodium chloride was carried away by the new portions of the calcium chloride mortar in the remote area, partially mixing with it.

Meneylyuk, A, Petrovskiy, A, Borisov, A, Nikiforov, A 
During the injection of a sodium hydrosilicate mortar, initial pressure of the injection was equal to 0 , while the final pressure was $4 \mathrm{~atm}$. The injection time was $1 \mathrm{~min}$ (equal to a full passage of the solution through a $1500 \mathrm{~mm}$ long section).

During the injection of the calcium chloride solution, initial injection pressure was $2 \mathrm{~atm}$, while the final pressure was $5 \mathrm{~atm}$. The injection time was equal to $1.5 \mathrm{~min}$.

The used soft-elastic waterproofing resin was a multi-component injection system consisting of components $A$ and $B$, which were mixed from the sub-components. The solution concentration determined the reaction time. The reaction times also depended on the temperature. All components were poured into the tank, and mixed. The injection was performed under a $2.5 \mathrm{~atm}$ pressure with a 5 min duration.

\section{METHODOLOGY OF THE SOIL FILTRATION COEFFICIENT DETERMINATION}

The soil filtration coefficient was determined without injection by the laboratory bench (Figures 6 and 7). The tests on the injected sandy soil were performed by the laboratory setup after the expiry of the technological break.

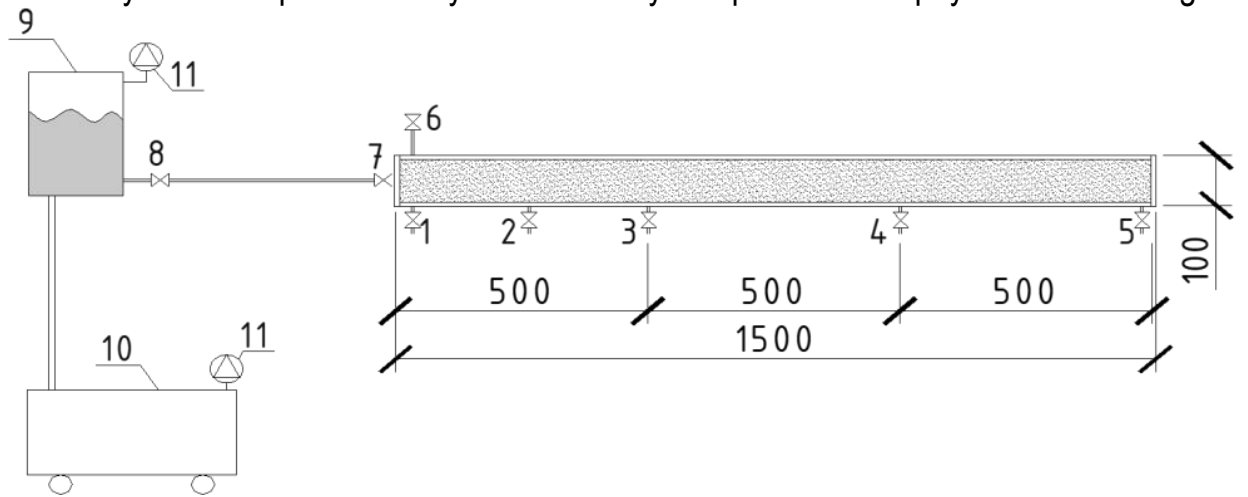

Figure 7 Scheme of the laboratory bench for the soil filtration coefficient determination: 1-8 - cranes; 9 - water tank; 10 - compressor; and 11 - gauge (dimensions are in millimeters)

The soil filtration coefficient was determined by the SPETSGEO device according to the following formula [41]: $k=\frac{Q}{T \times F},\left(\frac{c m}{\mathrm{~s}}\right)$

where $Q$ is the volume of water filtered during time $T, \mathrm{~cm}^{3} ; T$ is the filtration time, s; and $F$ is the tube section area, $\mathrm{cm}^{2}$.

The soil filtration coefficient values were compared with the soil filtration coefficient received in a laboratory bench for pure sand after receiving them for the pure sand from Eq. (1). The transition ratio was identified to drive the filtration coefficient values obtained in the laboratory bench using the developed technique to the method in [41].

\section{RESULTS OF THE EXPERIMENTAL STUDIES}

The experimental results denoted that the diagram of the soil filtration coefficient, which changed from the injection pressure, was constructed (Figures 8-11). Each line within the diagram showed how far from the solution injection source the indicator was measured. According to the data presented in the figures, the third-degree polynomial equations with approximation to the $R^{2} \leq 1$ level were constructed (Tables 3-5). Pressure $P(a t m)$ was indicated as " $x$," while the soil filtration coefficient was denoted as "y."

Figure 8 depicts the change of the soil filtration coefficient from the studied factors (i.e., pressure and distance from the injector source (injection by the bentonite-containing mortar)). Table 3 presents the analytical form of this relationship.

Let us now consider the graphs. Each graph represented the coefficient of permeability and the pressure of the injection compound dependence. Accordingly, an increase in the pressure was suggested to increase the filtering rate. The dependence was also observed by analyzing the polynomial equations (Table 3). The best soil filtration coefficient value injected by the bentonite-containing mortar was observed on a $500 \mathrm{~mm}$ distance from the injection source and at a pressure value equal to $0.8 \mathrm{~atm}$. The high value of the soil filtration coefficient at the 50

Meneylyuk, A, Petrovskiy, A, Borisov, A, Nikiforov, A 
$\mathrm{mm}$ distance from the injector can be explained by the relatively high pressure near the source of the mortar in the test bench eroded the soil injected previously. In conclusion, the injection was more efficient when the mortar source was closer, but not at the closest distance from the injector.

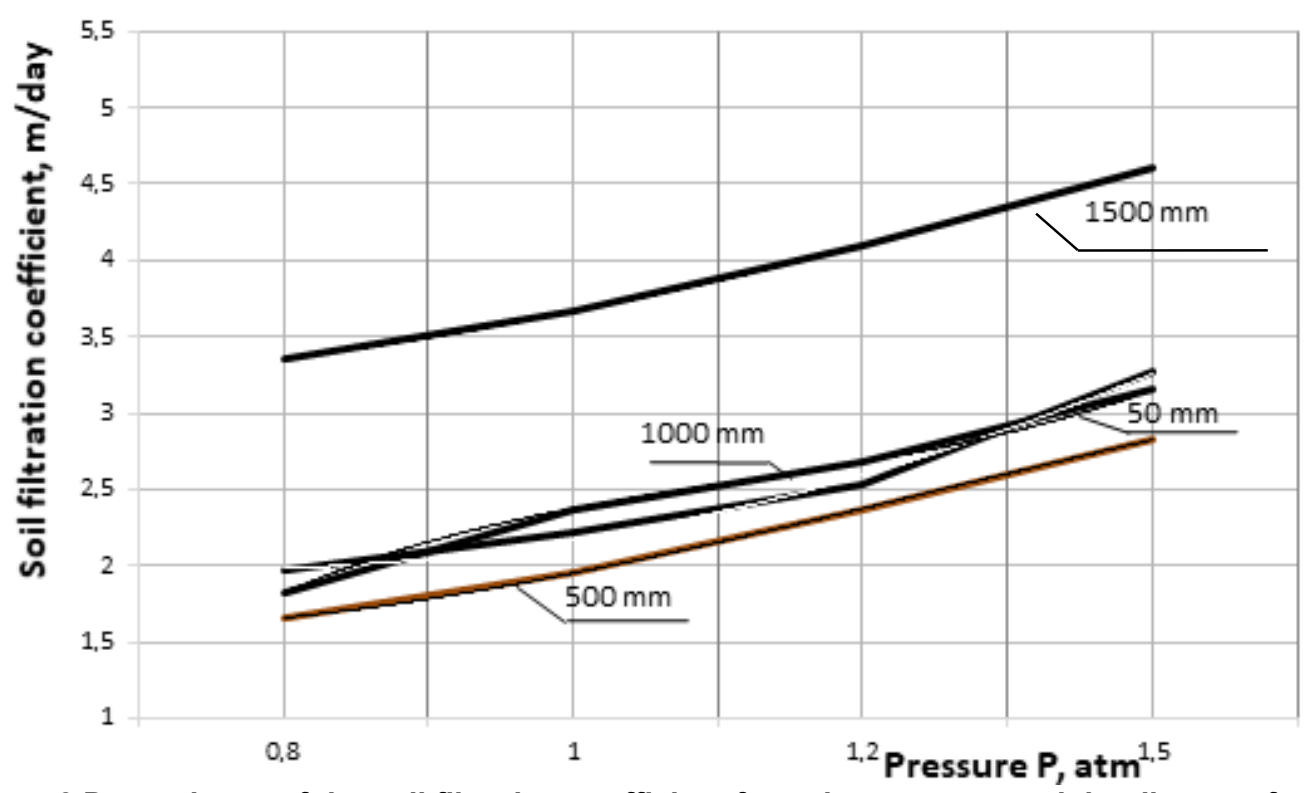

Figure 8 Dependence of the soil filtration coefficient from the pressure and the distance from the injection source (injection by the bentonite-containing mortar)

Table 3 Change of the soil filtration coefficient from the pressure and the distance from the injection source (injection by the bentonite-containing mortar)

\begin{tabular}{cll}
$\#$ & \multicolumn{1}{c}{ Equation } & Distance from the injection source \\
\hline 1 & $y=-0.007 x^{3}+0.1038 x^{2}+0.0443 x+3.215$ & $1500 \mathrm{~mm}$ \\
2 & $y=0.0599 x^{3}-0.3287 x^{2}+0.8229 x+1.4105$ & $1000 \mathrm{~mm}$ \\
3 & $y=0.0682 x^{3}-0.532 x^{2}+1.6708 x+0.6145$ & $500 \mathrm{~mm}$ \\
4 & $y=-0.0176 x^{3}+0.1712 x^{2}-0.0982 x+1.602$ & $50 \mathrm{~mm}$
\end{tabular}

The results showed an adequate range extension of the injectable mortar (for all laboratory settings: $1.5 \mathrm{~m}$ ). The anti-filtration properties of the resulting protective shield significantly improved because of the injection. The soil filtration coefficient decreased by 5.6 times, but they were unsatisfactory.

Figure 9 shows the dependence of the change of the soil filtration coefficient injected by calcium chloride and sodium hydrosilicate from the pressure and the distance from the injector. Table 4 presents the analytical form of this relationship. In conclusion, the nature of the indicator dependencies from the factors did not change significantly. However, the injection of the solution containing sodium chloride and calcium hydrosilicate reduced the filtration coefficient for any conditions of the protective shield arrangement (37 times down), but was still not enough to form a reliable shield.

Table 4 Change of the soil filtration coefficient from the pressure and the distance from the injection source (injection by the calcium chloride- and sodium silicate-containing mortar)

\begin{tabular}{ccc}
$\#$ & Equation & Distance from the injection source \\
\hline 1 & $y=-0.0017 x^{3}+0.0333 x^{2}-0.0405 x+0.7805$ & $1500 \mathrm{~mm}$ \\
2 & $y=0.0068 x^{3}-0.041 x^{2}+0.1512 x+0.1285$ & $1000 \mathrm{~mm}$ \\
3 & $y=0.0059 x^{3}-0.0237 x^{2}+0.0889 x+0.151$ & $500 \mathrm{~mm}$ \\
4 & $y=-0.0068 x^{3}+0.0525 x^{2}-0.0332 x+0.221$ & $50 \mathrm{~mm}$
\end{tabular}




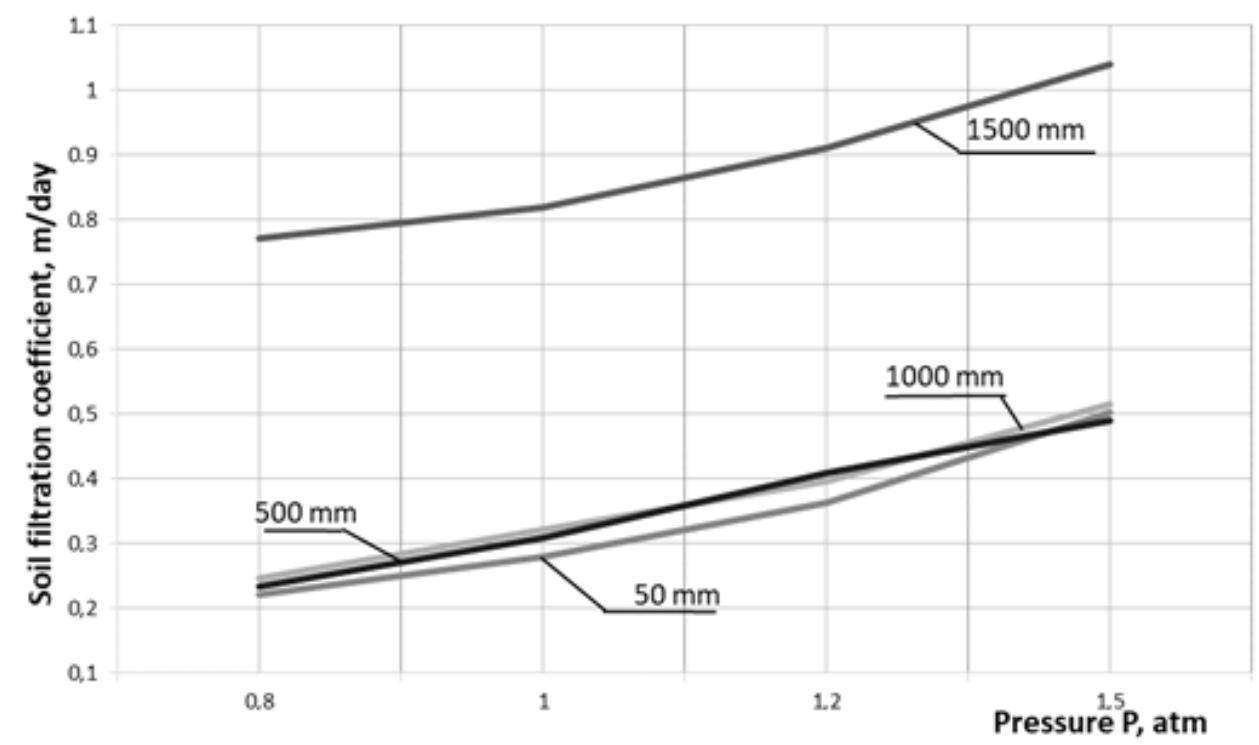

Figure 9 Dependence of the soil filtration coefficient from the pressure and the distance from the injection source (injection by the calcium chloride- and sodium hydrosilicate-containing mortar)

Figure 10 depicts the change dependence of the soil filtration coefficient from the pressure and the distance from the injector (injection by the waterproofing injection resin).

The curve obtained from the test results indicated that the injection solution did not spread to a $1500 \mathrm{~mm}$ point from the mortar source. This conclusion was obtained because the test results showed that the filtration coefficient value at this distance was similar to that in the non-injected sand test. The filtration coefficient value was zero at distances of 50 , 500,1000 , and $1250 \mathrm{~mm}$ from the injector, which suggested that the resulting protective shield was waterproof, and the mortar distribution radius was $1.25 \mathrm{~m}$. The reason for this situation was that the solution containing the waterproofing injection resin can guarantee zero filtration, but can be extended only on a distance of $1.25 \mathrm{~m}$ because of self-hardening.

In conclusion, the optimal pressure value was $0.8 \mathrm{~atm}$. Figure 11 shows the dependencies of the filtration coefficient from the injected composition and the distances from the injection source with a pressure value equal to $0.8 \mathrm{~atm}$. Table 5 lists the analytical forms of the dependencies.

In Table 5, the distance from the injector is designated as "x," while the soil filtration coefficient is as "y."

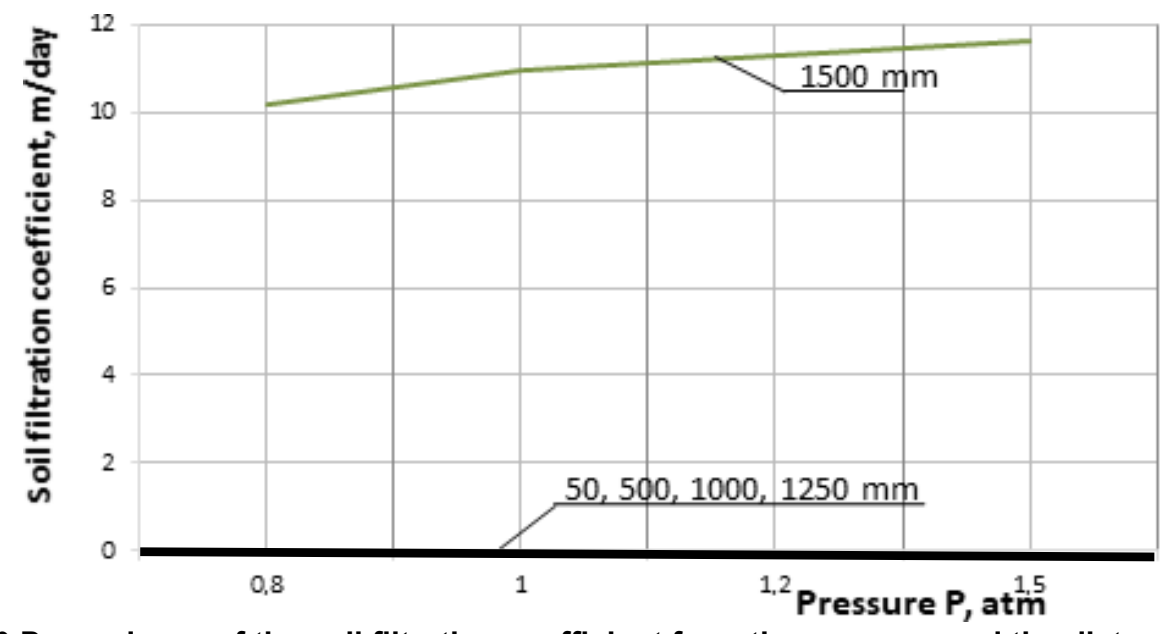

Figure 10 Dependence of the soil filtration coefficient from the pressure and the distance from the injection source (injection by the waterproofing injection resin)

Figure 11 provides an interpretation of the changing radius of the injection depending on the injection solution used (with a pressure value equal to $0.8 \mathrm{~atm}$ ). Considering each curve of the graph, we can see that the filtration 
coefficient had a maximum value at the maximum distance from the injector (i.e., $1500 \mathrm{~mm}$ ). This pattern was observed because each injection compound had not covered the maximum distance from the injector or was unevenly distributed.

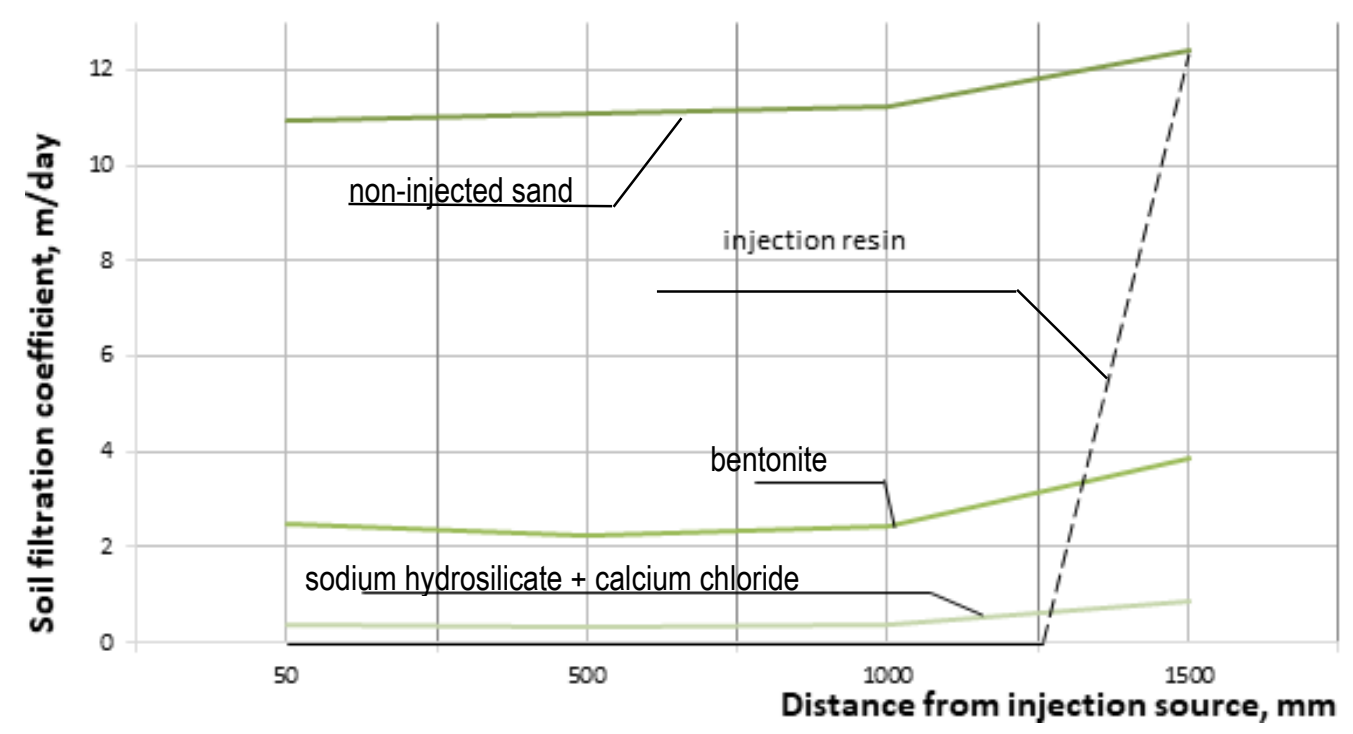

Figure 11 Comparison of the soil filtration coefficient injected by different compositions at different distances from the injector

Table 5 Change of the filtration coefficient from the injection composition and the distances from the injection source

\begin{tabular}{cll}
$\#$ & \multicolumn{1}{c}{ Equation } & \multicolumn{1}{c}{ Binding mortar component } \\
\hline 1 & $y=0.1622 x^{3}-0.96 x^{2}+1.8888 x+9.848$ & Non-injected sand \\
2 & $y=0.1242 x^{3}-0.5095 x^{2}+0.4053 x+2.46$ & Bentonite \\
3 & $y=0.0657 x^{3}-0.35 x^{2}+0.5323 x+0.14$ & Sodium hydrosilicate + calcium \\
4 & $y=1.8362 x^{3}-11.017 x^{2}+20.198 x-11.017$ & chloride \\
\end{tabular}

The analysis of the filtration coefficient curve obtained (injection by sodium silicate and calcium chloride) showed that the injected solution was evenly spread on the maximum distance from the injector $(1500 \mathrm{~mm})$. However, these filtration coefficient values were not sufficient for the waterproof shield arrangement.

The curve corresponding to the composition of the soft-elastic waterproof resin injection showed low filtration properties. The filtration coefficient value at a distance from the injector up to $1250 \mathrm{~mm}$ was zero. This injection mortar allowed the creation of a reliable waterproof protective shield according to the presented technology.

The average value of the sand filtration coefficient defined by the SPETSGEO device and that of the sand permeability determined by the developed technique on the laboratory test bench were taken to determine the ratio of the transition. Two permeability values of clean sand, which were obtained by different methods, were defined. According to their proportion, the transition ratio was calculated, which allowed bringing all the results to the method presented in [41]. The transition coefficient value was 1.3. Table 6 presents the results of all the performed tests considering the transitional rate.

The composition with bentonite powder referred to a weak waterproof according to the normative classification [40]. Meanwhile, the composition with calcium chloride and sodium hydrosilicate was nearly waterproof. The softelastic waterproofing injection resin showed the best indicators of waterproofness. It was waterproof, and the radius of the spread of this solution was $1.25 \mathrm{~m}$. 
Innovative technology of horizontal protective shield arrangement using injection

Table 6 Results of the experiments on the filtration coefficient according to the normative procedure [41] $(k=1.3)$

\begin{tabular}{ccccc} 
& \multicolumn{5}{c}{$\begin{array}{c}\mathbf{k}=\mathbf{1 . 3}) \\
\text { Distance from the } \\
\text { injection source }\end{array}$} & \multicolumn{4}{c}{$\begin{array}{c}\text { Value of the filtration coefficient (m/day) for the samples injected with the following mortars } \\
\text { (pressure value was equal to } 0.8 \text { atm): }\end{array}$} \\
\cline { 2 - 5 } & Non-injected sand & Bentonite & $\begin{array}{c}\text { Calcium chloride + hydrosilicate } \\
\text { sodium }\end{array}$ & Injection resin \\
\hline $1500 \mathrm{~mm}$ & 15.8808 & 5.0388 & 1.1336 & 14.3221 \\
$1000 \mathrm{~mm}$ & 14.6289 & 3.1759 & 0.468 & 0 \\
$500 \mathrm{~mm}$ & 14.4079 & 2.8938 & 0.429 & 0 \\
$50 \mathrm{~mm}$ & 14.2207 & 3.224 & 0.5044 & 0 \\
Average & 14.7846 & 3.5831 & 0.6338 & 0
\end{tabular}

\section{DETERMINATION OF THE COST EFFECTIVE WELL'S STEP WHILE ARRANGING THE UNDERGROUND PROTECTIVE SHIELD}

The two most expensive positions were observed while arranging the underground shield using horizontal directional drilling: large amount of waterproofing injection resin and drilling of underground wells. These positions were connected with each other. The larger the distance between the wells (which decreased the well drilling cost), the greater the need to use the injection mortar to form the protective shield, and vice versa.

An iterative calculation was held to determine the cost-effective process parameters. The diameter of the solution spread, and the well's step was consistently changed. The following initial data for the calculation of the assumptions was used:

- the solution was assumed to spread in the ground to form a circle;

- the radius of the solution was determined to ensure the intersectional placement of the distribution zones;

- the water percentage in the solution was $57.25 \%$, which was in accordance with the recommendations of the injection resin manufacturer;

- the cost of drilling $1 \mathrm{~m}$ of the $\varnothing 57 \mathrm{~mm}$ well was 20 EUR;

- the cost of 1 I of solution for injection with the waterproofing resin was 5 EUR; and

- the minimal distance between the $\varnothing 57 \mathrm{~mm}$ wells in the sandy soils was $300 \mathrm{~mm}$.

Table 7 presents the calculation results.

Table 7 Calculation of the technological parameters of resin injection with the use of horizontal directional drilling

\begin{tabular}{lccc}
\multicolumn{1}{c}{ Parameter name } & \multicolumn{3}{c}{ Calculation steps } \\
\cline { 2 - 4 } & Iteration 1 & Iteration 2 & Iteration 3 \\
\hline Distribution solution radius & $1.25 \mathrm{~m}$ & $0.5 \mathrm{~m}$ & $0.19 \mathrm{~m}$ \\
Step of the wells & $2 \mathrm{~m}$ & $0.8 \mathrm{~m}$ & $0.3 \mathrm{~m}$ \\
Volume of the distribution site & $4909 \mathrm{I}$ & $785 \mathrm{I}$ & $113 \mathrm{I}$ \\
Volume of the pore of the distribution site & $1325 \mathrm{I}$ & $211.95 \mathrm{I}$ & $30.51 \mathrm{I}$ \\
$\begin{array}{l}\text { Amount of injection resin for the distribution } \\
\text { site without water }\end{array}$ & $566.62 \mathrm{I}$ & $90.61 \mathrm{I}$ & $13.04 \mathrm{I}$ \\
Cost of the injection mortar & & & \\
Cost of materials for $1 \mathrm{~m}^{2}$ of the shield & $2924.49 \mathrm{EUR}$ & $467.66 \mathrm{EUR}$ & $67.30 \mathrm{EUR}$ \\
Total cost of the materials and drilling & $1299.77 \mathrm{EUR}$ & $519.63 \mathrm{EUR}$ & $197.95 \mathrm{EUR}$ \\
& 1307.84 EUR & $535.76 \mathrm{EUR}$ & $246.34 \mathrm{EUR}$
\end{tabular}

In conclusion, the total cost of the injection increased with the increasing distance between the injectors. The distance between the injectors was advisable to take $0.3 \mathrm{~m}$ to minimize the costs. 


\section{APPROBATION AND IMPLEMENTATION OF THE RESEARCH RESULTS}

The approbation and implementation of the research results were conducted in several directions:

1. full-scale experiment on a research stand with a size of $1.2 \times 1.5 \times 1.0 \mathrm{~m}$ and testing of the injection technology on the experimental site $(20 \times 10 \mathrm{~m})$ in Kyiv;

2. development of two technological process charts for the installation of the horizontal anti-filtration shields by the innovative technology presented in this work; and

3. arrangement of the horizontal anti-filtration shields under the sewage basin in Brno (Czech Republic) and under the storage rate in Kyiv.

The first direction showed that the distribution of the mortar in the full-scale conditions does not distort the results obtained in cylindrical laboratory bench.

On the second direction, two technological process charts were made for the installation of the horizontal anti-filtration shields using the innovative technology presented in this work. The technological process charts were developed for the installation of the anti-filtration shields under the burial grounds in the exclusion zone of the Chernobyl nuclear power plant. The radiation waste cemetery had a dimension of $32 \times 50 \mathrm{~m}$, with the soles of the waste buried at a $4 \mathrm{~m}$ depth from the earth surface level.

The third direction of the result implementation was the placement of the anti-filtration shield under the sewage basin in Brno (Czech Republic) to exclude groundwater contamination. Also an anti-filtration shield was created under the treatment station settler of Desniansky district of Kyiv according to the same organizational and technological decision, but at larger sizes of the field. The results of soil filtration coefficient, measured after the ground injection in field conditions, were equal to injections made in laboratory.

\section{CONCLUSIONS}

The following conclusions can be derived from the research results:

1. The analysis of the information sources showed a high actuality of search for the method of underground protective shield arrangement, low economic cost, and technical efficiency of the existing methods. The use of horizontal directional drilling and mortars prepared with the use of bentonite, sodium hydrosilicate and calcium chloride, and waterproofing soft-elastic injection resin could be effective for such work.

2. The developed technique and research equipment allowed the determination of the filtration coefficient of the sand injected by different compositions.

3. The comparison of the results of the determined filtration coefficient in the SPETSGEO device and the laboratory test bench helped define the transition rate for the experimental results (equal to 1.3).

4. The analysis of the results allowed the determination of the most effective decision for the shield arrangement in the tested sand soil. This solution contained soft-elastic waterproofing injection resin. A reliable shield can be created using such a solution, while the horizontal wells could be placed at a distance of $1.25 \mathrm{~m}$ from one another.

5. The step of the wells equal to $0.3 \mathrm{~m}$ was the most cost effective for the waterproofing resin injection using horizontal directional drilling in the tested sand soil.

\section{References}

[1] Amano, H.; Matsunaga, T.; Nagao, S.; Hanzawa, Y.; \& Watana, M. 1999: The transfer capability of long-lived Chernobyl radionuclides from surface soil to river water in dissolved forms. Organic Geochemistry, pp. 437-442, https://doi.org/10.1016/S0146-6380(99)00028-5

[2] Uchida, S.; Tagami, K.; Rühm, W.; \& Wirth, E. 1999: Determination of 99Tc deposited on the ground within the 30-km zone around the chernobyl reactor and estimation of 99Tc released into atmosphere by the accident. Chemosphere, pp. 2757-2766, https://doi.org/10.1016/S0045-6535(99)00210-6

[3] Uchida, S.; Tagami, K.; Wirth, E.; \& Rühm, W. 1999: Concentration levels of technetium-99 in forest soils collected within the 30-km zone around the Chernobyl reactor. Environmental Pollution, pp. 75-77, https://doi.org/10.1016/S0269$\underline{7491(98) 00210-3}$

Meneylyuk, A, Petrovskiy, A, Borisov, A, Nikiforov, A 
Innovative technology of horizontal protective shield arrangement using injection

[4] Bugai, D.; Skalskyy, A.; Dzhepo, S.; Kubko, Y.; Kashparov, V.; Van Meir, N.; \& Martin-Garin, A. 2012: Radionuclide migration at experimental polygon at Red Forest waste site in Chernobyl zone. Part 2: Hydrogeological characterization and groundwater transport modeling. Applied Geochemistry, pp. 1359-1374, https://doi.org/10.1016/j.apgeochem.2011.09.028

[5] Bugai, D.; Tkachenko, E.; Van Meir, N.; Simonucci, C.; Martin-Garin, A.; Roux, C.; \& Kubko, Y. 2012: Geochemical influence of waste trench no. 22T at Chernobyl Pilot Site at the aquifer: Long-term trends, governing processes, and implications for radionuclide migration. Applied Geochemistry, pp. 1320-1338, https://doi.org/10.1016/i.apgeochem.2011.09.021

[6] Nagao, S.; Aramaki, T.; Fujitake, N.; Matsunaga, T.; \& Tkachenko, Y. 2004: Radiocarbon of dissolved humic substances in river waters from the Chernobyl area. Nuclear Instruments and Methods in Physics Research Section B: Beam Interactions with Materials and Atoms, pp. 848-853, https://doi.org/10.1016/j.nimb.2004.04.156

[7] Dewiere, L.; Bugai, D.; Grenier, C.; Kashparov, V.; \& Ahamdach, N. 2004: 90Sr migration to the geo-sphere from a waste burial in the Chernobyl exclusion zone. Journal of Environmental Radioactivity, pp. 139-150, https://doi.org/10.1016/j.jenvrad.2004.01.019

[8] Roux, C.; Le Gal La Salle, C.; Simonucci, C.; Van Meir, N.; Keith Fifield, L.; Diez, O.; \& Lancelot, J. 2014: High 36Cl/Cl ratios in Chernobyl groundwater. Journal of Environmental Radioactivity, pp. 19-32, https://doi.org/10.1016/i.jenvrad.2014.07.008

[9] Le Gal La Salle, C.; Aquilina, L.; Fourre, E.; Jean-Baptiste, P.; Michelot, J.-L.; Roux, C.; \& Lancelot, J. 2012: Groundwater residence time downgradient of Trench No. 22 at the Chernobyl Pilot Site: Constraints on hydrogeological aquifer functioning. Applied Geochemistry, pp. 1304-1319, https://doi.org/10.1016/i.apgeochem.2011.12.006

[10] Aquilina, L.; Matray, J.; \& Lancelot, J. 2012: 25 years after the Chernobyl power plant explosion: Management of nuclear wastes and radionuclide transfer in the environment. Applied Geochemistry, pp. 1291-1296, https://doi.org/10.1016/i.apgeochem.2012.04.010

[11] Dmitriev, V. \& Zhivoderov, V. N. 1994: Characteristics of organization and execution of ground-water protection for elimination of failure consequences at the Chernobyl Nuclear Power Plant. Soil Mechanics \& Foundation Engineering, pp. 24-27, https://doi.org/10.1007/BF02336653

[12] Kashparov, V.; Yoschenko, V.; Levchuk, S.; Bugai, D.; Van Meir, N.; Simonucci, C.; \& Martin-Garin, A. 2012: Radionuclide migration in the experimental polygon of the Red Forest waste site in the Chernobyl zone - Part 1 : Characterization of the waste trench, fuel particle transformation processes in soils, biogenic fluxes and effects on biota. Applied Geochemistry, pp. 1348-1358, https://doi.org/10.1016/j.apgeochem.2011.11.004

[13] E. Lee, W.; I. Ojovan, M.; \& Jantzen C. 2013: Radioactive Waste Management and Contaminated Site Clean-up. Cambridge: Woodhead Publishing Limited.

[14] Evangeliou, N.; Hamburger, T.; Talerko, N.; Zibtsev, S.; Bondar, Y.; Stohl, A.; \& P. Moeller, A. 2016: Reconstructing the Chernobyl nuclear power plant (CNPP) accident 30 years after. A unique database of air concentration and deposition measurements over Europe. Environmental Pollution, pp. 408-418, https://doi.org/10.1016/i.envpol.2016.05.030

[15] Shcheglov, A.; Tsvetnova, O.; \& Klyashto, A. 2014: Biogeochemical cycles of Chernobyl-born radionuclides in the contaminated forest ecosystems. Long-term dynamics of the migration processes. Journal of Geochemical Exploration, pp. 260-266, https://doi.org/10.1016/j.gexplo.2014.05.026

[16] Voitsekhovitch, O.; Nasvit, O.; Los'y, I.; \& Berkovs, V. 1997: Present thoughts on the aquatic countermeasures applied to regions of the Dnieper river catchment contaminated by the 1986 Chernobyl accident. Studies in Environmental Science, pp. 75-85, https://doi.org/10.1016/S0166-1116(09)70083-4

[17] Adamovich, A. 1980: Grouting and grout curtain in the hydropower construction (Zakreplenie gruntov i protivofil'tracionnye zavesy v gidrojenergeticheskom stroitel'stve): Moskow: Jenergiya.

[18] Alimov, A. G. 2008: Antifiltration protection of canals and reservoirs (Protivofil'tracionnaja zashhita kanalov i vodoemov): Gidrotehnicheskoe stroitel'stvo, pp. 36-42. (in Ukrainian)

[19] Zadgenidze, V. 2005: Protecting areas from flooding (Zashhita territorij ot podtoplenija. Praktikum: metod. posob.): Odessa: OGASA.

[20] Ammosova, J. M. 1989: Soil protection against chemical pollution (Ohrana pochv ot himicheskih zagrjaznenij): Moskow: MGU. (in Ukrainian)

[21] Val'kov, V. F.; Kazeev, K. S.; \& Kolesnikov, S. I. 2004: Soil Ecology: A textbook for university students (Jekologija pochv : uchebnoe posobie dlja studentov vuzov): Rostov-na-Donu: UPL RGU. (in Ukrainian)

[22] Chernuhin, A. \& Galinskij, A. 1997: Application of the method "a diaphragm underground wall" for the localization of radioactive waste disposal points (Primenenie sposoba "stena $v$ grunte" dlja lokalizacii punktov zahoronenija radioaktivnyh othodov). Stroitel'noe Proizvodstvo, pp. 7-10.

[23] Skonberg, E.; E. Tammi, C.; M. Desilets, A.; Srivastava, V.; \& M. Evans. 2002: Horizontal Directional Drilling Best Management Practices Manual. New York: GRI.

Meneylyuk, A, Petrovskiy, A, Borisov, A, Nikiforov, A 
Innovative technology of horizontal protective shield arrangement using injection

[24] Zayed, T. \& Mahmoud, M. 2013: Data acquisition and factors impacting productivity of horizontal directional drilling HDD: Tunnelling and underground space technology, pp. 63-72, https://doi.org/10.1016/j.tust.2012.08.005

[25] Hungerford, F. \& Ren, T. 2014: Directional drilling in unstable environments. International Journal of Mining Science and Technology, pp. 397-402, https://doi.org/10.1016/j.jimst.2014.03.019

[26] Imbert, C. \& Villar, M. 2006: Hydro-mechanical response of a bentonite pellets/powder mixture upon infiltration. Applied Clay Science, pp. 197-209, https://doi.org/10.1016/j.clay.2006.01.005

[27] Villar, M. 2006: Infiltration tests on a granite/bentonite mixture: Influence of water salinity. Applied Clay Science, pp. 96109, https://doi.org/10.1016/j.clay.2005.07.007

[28] Xu, L.; Ye, W.; Chen, B.; Chen, Y.; \& Cui, Y. 2016: Experimental investigations on thermo-hydro-mechanical properties of compacted GMZ01 bentonite-sand mixture using as buffer materials. Engineering Geology, pp. 46-54, https://doi.org/10.1016/i.enggeo.2016.08.015

[29] Vaunat, J. \& Gens, A. 2005: Analysis of the hydration of a bentonite seal in a deep radioactive waste repository. Engineering Geology, pp. 317-328, https://doi.org/10.1016/j.enggeo.2005.06.014

[30] Chegbeleh, L.; Yidana, S.; Nishigaki, M.; \& Achampong, F. 2014: Comparative study on the application of ethanolbentonite slurry and salt-bentonite slurry as effective injection materials for barrier sealing. Applied Clay Science, pp. 40-45, https://doi.org/10.1016/j.clay.2013.11.026

[31] Holmboe, M.; Wold, S.; \& Petterson, T. 2011: Effects of the injection grout silica sol on bentonite. Physics and Chemistry of the Earth, pp. 1580-1589, https://doi.org/10.1016/j.pce.2011.07.026

[32] Mander, R. 1981: Use of resins in road and bridge construction and repair. International Journal of Cement Composites and Lightweight Concrete, pp. 27-39, https://doi.org/10.1016/0262-5075(81)90020-8

[33] Nowamooz, H. 2016: Resin injection in clays with high plasticity. Comptes Rendus Mécanique, pp. 797-806, https://doi.org/10.1016/i.crme.2016.09.001

[34] Thunga, M.; Bauer, A.; \& Obusek, K. 2014: Injection repair of carbon fiber/bismaleimide composite panels with bisphenol E cyanate ester resin. Composites Science and Technology, pp. 174-181, https://doi.org/10.1016/i.compscitech.2014.05.024

[35] Galins'kij, O. \& Menejljuk, O. 2011: The method of arranging the screen under construction E 02 D 29/00 (Sposib ulashtuvannja ekrana pid sporudoju). 65550. 2011. Ukrainian.

[36] Galins'kij, O. \& Menejljuk, O. 2012: The method of arranging the screen under construction E 02 D 29/00 (Sposib ulashtuvannja ekrana pid sporudoju). 73600. 2012. Ukrainian.

[37] Petrovskij, A.; Galins'kij, O.; \& Menejljuk, O. 2014: The method of arrangement of anti-drainage curtain under construction E 02 B $3 / 00$ (Sposib ulashtuvannja protifil'tracijnoï zavisi pid sporudoju). 91704. 2014. Ukrainian.

[38] Chapovskij, A. 1975: Laboratory work on soil science and soil mechanics (Laboratornye raboty po gruntovedeniju i mehanike gruntov): Moskow: Nedra.

[39] Churakov, A. 1976: Production of special works in hydraulic engineering (Proizvodstvo special'nyh rabot v gidrotehnicheskom stroitel'stve): Moskow: Stroyizdat.

[40] Soils. Classification Grunti. Klasifikacija - State Standard of Ukraine - DSTU B V.2.1-2-96 GOST 25100-95: 1996: http://normativ.com.ua/types/tdoc353.php, Accessed 18 December 2017

[41] Soils. Laboratory methods for determining the filtration coefficient - State Standard of the USSR (Grunty. Metody laboratornogo opredelenija kojefficienta fil'tracii - $\quad$ GOST 25584-90): 1990: http://www.gosthelp.ru/text/GOST2558490GruntyMetodyla.html, Accessed 18 December 2017

Please cite this article as:

Meneylyuk, A, Petrovskiy, A, Borisov, A, Nikiforov, A: Innovative technology of horizontal protective shield arrangement using injection, Electronic Journal of the Faculty of Civil Engineering Osijek-e-GFOS, 15, pp. 36-49, https://doi.org/10.13167/2017.15.4 